\title{
The use of cobs, a by-product of maize grain, for energy production in anaerobic digestion
}

\author{
Massimo Blandino, ${ }^{1}$ Claudio Fabbri, ${ }^{2}$ Mariangela Soldano, ${ }^{2}$ Carlo Ferrero, ${ }^{3}$ \\ Amedeo Reyneri ${ }^{1}$ \\ ${ }^{1}$ Department of Agricultural, Forest and Food Sciences, University of Torino, Grugliasco (TO); \\ ${ }^{2}$ Research Centre on Animal Production (C.R.P.A. S.p.A.), Reggio Emilia; ${ }^{3}$ Consorzio Agricolo \\ Piemontese per Agroforniture e Cereali (C.A.P.A.C.) soc. coop. agr., Torino, Italy
}

\begin{abstract}
Owing to the rising energy demand and the conflict between food, feed and energy crops for agricultural land, there is a growing need for alternative biomasses for energy purposes. New developments in harvesting technology have created the possibility of harvesting cobs as a by-product of maize grain harvesting. The aim of the present work has been to evaluate the potential and limitations of maize cob utilisation in an anaerobic digestion chain, considering the main agronomic, productive and qualitative traits. Maize grain and cob yields as well as the moisture content of samples collected from 1044 (farm) fields (located) in North West Italy have been determined over the 2012 growing season. Moreover, 27 representative fields were harvested using a modified combine-harvester that is able to collect maize grains and
\end{abstract}

Correspondence: Massimo Blandino, Department of Agricultural, Forest and Food Sciences, University of Torino, Largo Paolo Braccini 2, 10095 Grugliasco (TO), Italy.

Tel.: +39.011.6708895 - Fax. +39.011 .6708798 .

E-mail: massimo.blandino@unito.it

Key words: Maize cob; biogas, methane; sustainable production of biomass; energy crops.

Acknowledgements: the authors would like to thank Carlo Vanzetti and Angelo Oddennino (Cooperativa Agricola Speranza, Candiolo, Italy), Giulio Testa, Giacomo Sala, Matteo Calcagno (University of Torino) and Andrea Pilati (C.A.P.A.C.) for their precious help and cooperation in the work.

Funding: the research was conducted with the financial support of the Regione Piemonte (Rural Development Programme F.E.A.R.S. 2007/2013), as a part of the ENERCOB project.

Conference presentation: SIA XLIV Congress, Bologna, 2015.

Received for publication: 29 January 2016.

Revision received: 1 April 2016.

Accepted for publication: 2 April 2016.

(C) Copyright M. Blandino et al., 2016

Licensee PAGEPress, Italy

Italian Journal of Agronomy 2016; 11:754

doi:10.4081/ija.2016.754

This article is distributed under the terms of the Creative Commons Attribution Noncommercial License (by-nc 4.0) which permits any noncommercial use, distribution, and reproduction in any medium, provided the original author(s) and source are credited. threshed cobs separately. The chemical composition and biochemical methane potential (BMP) of the cobs have been analysed.

The relative potential yield of maize cobs was established as $18.7 \%$ of the grain mass, while the wet cob yield recorded in the field after mechanical harvesting was $1.6 \mathrm{t} \mathrm{ha}^{-1}$. The total solid content was $60 \%$. Fibre fractions represented over $85 \%$ of the dry cob matter, lignin content was about $16 \%$, while the protein, ash, lipids and macro-elements (nitrogen, phosphorus, potassium) contents were very low compared to the whole-plant maize used for silage. The average BMP of wet threshed cob was $250 \pm 20 \mathrm{Nm}^{3} \mathrm{t} \mathrm{VS}^{-1}$.

Collected data have underlined that maize cobs could be used as a sustainable feedstock for anaerobic digestion processes.

\section{Introduction}

Maize is one of the most frequently planted crops throughout the world because of its high productivity for food, feed and chemical purposes. The use of this crop as a renewable energy source has recently been increasing, due to the clear economic advantage compared to other crops (Stürmer et al., 2011).

Whole-plant maize silage, harvested at the dough stage, is the main energy crop generally used for this process, since it has the highest yield potential of all the crops cultivated in Central and Southern Europe (Amon et al., 2007), and it offers a suitable substrate for anaerobic fermentation. However, with the growth in the number of anaerobic digestion plants (GSE, 2015), there is an increasing need for alternative biomasses, even from agricultural residues, which are suitable for this energy purpose, but which do not have a negative impact on the use of maize for the more conventional food and feed chains.

Among the broad variety of agricultural residues, maize cobs represent an interesting source of biomass, and their advantageous composition could allow their use for both direct combustion of dry biomass (Lizotte et al., 2015) and for the anaerobic fermentation process (Li et al., 2015).

In ordinary harvesting practices, maize cobs are generally discarded and left unused on top of the fields after the grain harvest (Sokhansanj et al., 2002). However, new developments in harvesting technology, based on the Corn Cob Mix method (Wehrspann, 2009), have created the possibility of obtaining cobs as a by-product of maize grain harvesting, without impurities or any significant operating costs.

Maize cobs could be used as an alternative energy source, while taking advantage of traditional maize cultivation practices for grain, without penalising the traditional uses. The main agronomic, productive and qualitative traits of maize cob have been reported in this paper in relationship to grain production, in order to evaluate the potential and limitations of cob utilisation in the anaerobic digestion chain. 


\section{Materials and methods}

Ear maize samples have been manually collected at the end of maturity from a $4.5 \mathrm{~m}^{2}$ area in 1044 fields located in North West Italy during the 2012 growing season, in order to cover different production situations. The ears were weighed, counted and then shelled using an electric sheller. The obtained grains and cobs were weighed in order to obtain the grain and cob yield, while the moisture content was determined by means of a Dickey-John GAC2000 (Dickey-John Corp., Auburn, IL, USA) grain analysis meter (grains) and an electronic moisture balance Eurotherm (Gibertini Elettronica s.r.l., Novate Milanese, MI, Italy) (cob).

Moreover, 27 representative fields, selected from among the fields manually sampled, were mechanically harvested using a modified axial flow combine-harvester (Axial-flow 7130; Case IH, Racine, WI, USA), which is able to collect maize grains and threshed cobs separately. Combine-harvester was equipped with a specific cob collecting apparatus, consisting of a threshing and separating system, a dedicated cob tank and an unloading device.

The chemical composition (fibre, total organic carbon, protein lipid, ash, nitrogen, phosphorus and potassium contents) and the biochemical methane potential (BMP) were measured in threshed cob samples obtained after mechanical harvesting, and were compared with a standard whole-plant maize silage from the same growing season and area. Batch experiments for BMP determination were conducted according to the UNI EN ISO 11734 standard (UNI, 2004). Tests were carried out in 1.35 litre, working volume, glass reactors placed in a controlled temperature at $38 \pm 0.2^{\circ} \mathrm{C}$. The substrate was mixed with fresh inoculum, taken from an agriculture biogas plant (fed with cattle slurry) and preincubated for 7 days before use. A buffer solution and a trace element solution were added to obtain the essential pool of salts and micro and macronutrients for anaerobic bacterial growth. The nutrient medium is prepared according to the chemicals and their concentration in the reactor indicated in the UNI EN ISO 11734 standard (UNI, 2004). If necessary the $\mathrm{pH}$ is adjusted with acid or base up to $7 \pm 0.2$. The headspace of each reactor, loaded with the mixture, was flushed with nitrogen gas till the oxygen concentration in the headspace was lower than $2 \%$. The produced biogas was measured by manometric method according to the standard and by a mass flow controller device (Soldano et al., 2012). The BMP test measures the amount of biogas produced from the degradation of an organic substrate, and other kinetic information and the results are expressed as normal cubic meters of methane per $\mathrm{kg}$ of volatile solids $\left(\mathrm{Nm}^{3} \mathrm{t} \mathrm{VS}^{-1}\right)$.

An investigation of the compatibility of cob conservation, through ensilage, was conducted according to two different approaches based on the use of polyethylene films: pure cobs were ensiled through a round bale system (dimension $1.20 \times 1.15 \mathrm{~m}$, ORKEL MP2000 Compactor; ORKEL AS, Fannrem, Norway), while a mixture of cobs and whole-plant maize (50-50\%) was co-ensiled in a silo bag system (bag $60 \mathrm{~m}$ long and $2.7 \mathrm{~m}$ in diameter, using the bagging machine Rotopress II, Apiesse s.r.l., Pizzighettone, CR, Italy). Round bales and silo bag were stored outside with no other protection from the weather. At 120 $\mathrm{d}$ from ensiling, cob samples were collected from both silage systems

Table 1. Maize cob and grain yield parameters in experimental samples collected in North West Italy during the 2012-growing season.

\begin{tabular}{|c|c|c|c|c|}
\hline Parameter & Unit & Average & Min & $\operatorname{Max}$ \\
\hline Wet weight of the ear & (g) & 305 & 115 & 490 \\
\hline Wet weight of the cob & (g) & 47 & 23 & 99 \\
\hline Grain yield ( $14 \%$ moisture content) & $\left(\mathrm{t} \mathrm{ha}^{-1}\right)$ & 15.1 & 7.8 & 19.1 \\
\hline Cob yield (w.w.) & $\left(\mathrm{t} \mathrm{ha}^{-1}\right)$ & 3.0 & 1.8 & 4.1 \\
\hline Cob yield (d.w.) & $\left(\mathrm{t} \mathrm{ha}^{-1}\right)$ & 1.9 & 1.3 & 2.4 \\
\hline Ear length & $(\mathrm{cm})$ & 21 & 15 & 25 \\
\hline Cob (w.w.)/grain (14\%)* & $(\%)$ & 18.7 & 12.2 & 35.2 \\
\hline $\operatorname{Cob}\left(\right.$ d.w.)/grain $(14 \%)^{\circ}$ & (\%) & 11.6 & 6.7 & 25.6 \\
\hline Grain moisture content & $(\%)$ & 24.6 & 17.6 & 42.5 \\
\hline Cob moisture content & $(\%)$ & 41.8 & 21.1 & 63.9 \\
\hline
\end{tabular}

The reported data refer to 1044 maize samples collected by hand in farm and experimental fields located in North West Italy and shelled in the laboratory. The measured parameters do not refer to mechanically harvested samples. *Percentage rate between the cob yield expressed as wet weight (w.w.) and grain yield at a $14 \%$ moisture content; ${ }^{\circ}$ percentage rate between the cob yield expressed as dry weight (d.w.) and grain yield at a $14 \%$ moisture content.

Table 2. Average composition and biochemical methane potential expressed per $t$ of volatile solids of maize cob vs standard maize silage obtained in the same growing season and area.

\begin{tabular}{|c|c|c|c|}
\hline Parameter & Unit & Threshed maize cob & Whole-plant maize for silage \\
\hline Dry matter & $\%$ & $60.9 \pm 5.5$ & $31.9 \pm 0.4$ \\
\hline NDF & g $100 \mathrm{~g}^{-1}$ d.m. & $85.9 \pm 3.9$ & $40.2 \pm 10.8$ \\
\hline $\mathrm{ADF}$ & g $100 \mathrm{~g}^{-1}$ d.m. & $45.5 \pm 2.1$ & $25.1 \pm 0.6$ \\
\hline $\mathrm{ADL}$ & g $100 \mathrm{~g}^{-1}$ d.m. & $16.6 \pm 5.4$ & $4.9 \pm 1.8$ \\
\hline Total organic carbon & g $100 \mathrm{~g}^{-1}$ d.m. & $54.85 \pm 1.33$ & $55.75 \pm 5.43$ \\
\hline Protein & g $100 \mathrm{~g}^{-1}$ d.m. & $3.37 \pm 0.68$ & $7.44 \pm 0.058$ \\
\hline Ash & g $100 \mathrm{~g}^{-1}$ d.m. & $2.44 \pm 0.94$ & $5.13 \pm 0.60$ \\
\hline Lipid & g $100 \mathrm{~g}^{-1}$ d.m. & $0.68 \pm 0.25$ & $3.86 \pm 1.11$ \\
\hline Nitrogen & g $100 \mathrm{~g}^{-1}$ d.m. & $0.56 \pm 0.11$ & $1.24 \pm 0.01$ \\
\hline Phosphorus & g $100 \mathrm{~g}^{-1}$ d.m. & $0.073 \pm 0.02$ & $0.22 \pm 0.03$ \\
\hline Potassium & g $100 \mathrm{~g}^{-1}$ d.m. & $0.73 \pm 0.16$ & $0.98 \pm 0.04$ \\
\hline BMP & $\mathrm{Nm}^{3} \mathrm{CH}_{4} \mathrm{t} \mathrm{VS}^{-1}$ & $250 \pm 20$ & $350 \pm 18$ \\
\hline
\end{tabular}

The reported cob data refer to the average of 27 samples \pm standard deviation collected through mechanical harvesting of maize for grain in the 2012 growing season in North West Italy. The reported maize data for silage refer to 6 samples collected in the same growing seasons and area and analysed in the same laboratory. NDF, neutral detergent fibre; ADF, acid detergent fibre; ADL, acid detergent lignin; BMP, biochemical methane potential. 
and chemically analysed in order to evaluate the $\mathrm{pH}$ value and their composition.

Considering the average value and standard deviation of all samples collected, coefficient of variation (CV) was calculated for maize cob and grain yield parameters and their composition. The relationship between the grain moisture at harvest and cob moisture was studied through linear regression analysis. The SPSS for Windows statistical package, Version 21.0 (SPSS Inc., Chicago, IL, USA), was used for the statistical analyses.

\section{Results}

In order to ensure an optimal use of the maize cobs and to accurately assess their economic value, it is necessary to have reliable predictions of the level of dry matter production at a farm and territorial scale. Thus, cob yield and moisture content were parameterised to those of known and routinely measured maize grain.

As the average production is $15 \mathrm{tha}^{-1}$ of grain with moisture content of $24.6 \%$, a potential cob harvest of $3.0 \mathrm{t} \mathrm{ha}^{-1}$, with an average moisture content of $42 \%$ could be expected (Table 1). On average, the relative yield of maize cobs is $18.7 \%$ of the grain mass. The wet cob yield recorded in the field after harvesting with the modified combine-harvester was $1.6 \mathrm{tha}^{-1}$, and varied between 1 to $2 \mathrm{tha}^{-1}$, at varying of the production situations and of the efficiency of the harvesting system. The average grain yield obtained in the compared conditions was $11.7 \mathrm{t} \mathrm{ha}^{-1}$ (expressed at a 14\% moisture content). In Italy, an area of approximately 800,000 ha of maize is cultivated for grain production (FAOSTAT, 2014), therefore an overall potential of 1.1 million $t$ per year of maize cobs can be hypothesised for use as raw material for energy purposes. Comparing the manual harvest with the combine-harvester, average cob losses in the field of $20 \%$ were highlighted, due to an incorrect separation from other debris of generally lighter density than the cobs, such as stalk portions, leaves, husks, tassels or silks, which fall to the ground. The collected data always reported a maximum size of 30 mm of the threshed cobs: $21 \%$ of the material showed a particle size smaller than $5.5 \mathrm{~mm}, 28 \%$ between 5.5 and $10 \mathrm{~mm}, 46 \%$ between 10 and 20 , while $5 \%$ showed a size higher than $20 \mathrm{~mm}$. The smaller dimension of the threshed cob after mechanical harvesting could allow its direct use for anaerobic fermentation, without the necessity of any further grinding or threshing operations. However, since the average density of the threshed wet cob was low $\left(200 \mathrm{~kg} \mathrm{~m}^{-3}\right)$, it is necessary to set up the harvest management in order to minimize transportation. The operability of the combined harvester was not penalised by the simultaneous collection of cobs and grains. However, the times necessary for unloading the cob tank were about 25-30\% higher than those of the grains, but this higher time was mitigated by the possibility of unloading two products simultaneously. Except for when there are unusual and extreme grain harvesting conditions with moisture content higher than $34 \%$ or lower than $18 \%$, the relationship between the moisture content of the grain and cob is linear $(y=2.26 x-13.9)$. Since grain moisture explains more than $72 \%$ of the variability of the cob moisture $\left(\mathrm{R}^{2}=0.726 ; \mathrm{P}<0.001\right)$ it is possible to identify this parameter, with an acceptable accuracy, by more easily measuring the grain at harvest.

The threshed cobs collected by means of the combine-harvester were chemically analysed in order to evaluate their composition and their BMP. Fibre fractions represented over $85 \%$ of the dry matter of the cob (Table 2): the hemicellulose, which could be used easily by microorganisms, was 40\%; the cellulose, used in anaerobic digestion but with longer degradation times was $29 \%$; while the lignin was over $16 \%$. The protein, ash, lipids, macro-elements (nitrogen, phosphorus, potassium) contents were very low compared to the whole-plant maize used for silage, and confirm previous results (Jansen and Lübberstedt, 2012). The average biogas yield of the wet threshed cob was $481 \pm 39$ $\mathrm{Nm}^{3} \mathrm{tVS}^{-1}$, with a methane percentage of $52 \pm 0.7 \%$, which resulted in a BMP of $250 \pm 20 \mathrm{Nm}^{3} \mathrm{tVS}^{-1}$. Considering the content of volatile solids in the threshed cob, it emerges that the methane yield was $146 \pm 8 \mathrm{Nm}^{3} \mathrm{t}$ w.w. ${ }^{-1}$, which is equivalent to a standard maize silage rate of $1.32 \pm 0.08$ $\mathrm{t} \mathrm{t}^{-1}$. Standard maize silage equal to $111 \mathrm{Nm}^{3} \mathrm{t}$ w.w. ${ }^{-1}$ is an average value from the Research Centre on Animal Production (C.R.P.A.) BMP database (Soldano et al., 2012). The value is similar to that found on average in literature (Amon et al., 2007).

Maize cobs, which essentially consist of hemicellulose and cellulose, with low percentages of lignin and ash, constitute a material with a high energy potential, with advantages in the case of their use in anaerobic digestion.

Compared to the production of grain, the maize cob yield has been found to be influenced less by the environmental conditions and the applied agronomic techniques (planting and harvesting date, fertilisation, disease control). The overall CV of cob yield was 15.2 , while that of grain yield was 17.6. Comparing different environments, hybrids and cropping systems, the cob composition has resulted to be more stable than that of whole-plant maize silage or that of other biomasses, consisting of larger fractions of vegetative parts (leaves, stalks) which undergo rapid senescence processes. This characteristic could facilitate the introduction of cobs into feeding programs for anaerobic digesters. Moreover, pure cobs (round bale) or a mixture of cobs and whole-plant maize (silo bag) could easily be ensiled using conventional farm techniques and equipment: the attack of fermentable carbohydrates by lactic acid bacteria with both systems resulted in a reduction of the $\mathrm{pH}$ of the cobs to 4.0 4.2 (data not shown). The acidification process, associated with the high fibre and the low protein and lipid contents, effectively reduced the risk of cob degradation. This by-product can be used in different ways: fresh, during the maize grain harvesting period, or stored through silage techniques, alone or in mixture with whole-plant maize silage, for use throughout the entire year. From the environmental sustainability point of view, since most of the maize residue remains on the field after cob and grain harvesting, and because nutrient removal from cob harvesting is relatively low, the impact on soil organic matter levels is likely to be low. In this context, Graham et al. (2007) stated that the limit value of removed maize stover without any negative impact on soil fertility is about $28 \%$, while in the present experiment the removal of cob was always lower than $20 \%$.

\section{Conclusions}

The sampling and analysis of maize cobs in different production situations have highlighted how this maize grain cultivation by-product could be of interest for energetic purposes after anaerobic digestion.

Bio-energy chain of cob from maize for grain cultivation could represent an opportunity to improve the sustainability of energy production through anaerobic digestion, by reducing the agricultural area dedicated to the cultivation of energy crops. Moreover, the development of this chain could ensure an integration of income for cereal farms.

Further studies are still required to define the best organisational structure that could lead to the success of this by-product chain.

\section{References}

Amon T, Amon B, Kryvoruchko V, Zollitsch W, Mayer K, Gruber L, 2007. Biogas production from maize and dairy cattle manure. Influence 
of biomass composition on the methane yield. Agric. Ecosyst. Environ. 118:173-82.

FAOSTAT, 2014. Food and Agriculture Organization of the United Nations, Statistic division. Available from: http://faostat3.fao.org/ download/Q/QC/E

Graham RL, Nelson R, Sheehan J, Perlack RD, Wright LL, 2007. Current and potential U.S. corn stover supplies. Agron. J. 99:1-11.

GSE (Gestore Servizi Energetici), 2015. Statistical Report 2015 Renewableenergy power plants. Available from: http//www.gse.it/it/Statistiche /RapportiStatistici/Pagine/default.aspx

Li W, Li Q, Zheng L, Wang Y, Zhang J, Yu Z, Zhang Y, 2015. Potential biodiesel and biogas production from corncob by anaerobic fermentation and black soldier fly. Bioresource Technol. 194:276-82.

Lizotte PL, Philippe Savoie P, De Champlain A, 2015. Ash content and calorific energy of corn stover components in Eastern Canada. Energies 8:4827-38.

Jansen C, Lübberstedt T, 2012. Turning maize cobs into a valuable feedstock. Bioenerg. Res. 5:20-31.
Sokhansanj S, Turhollow A, Cushman J, Cundiff J, 2002. Engineering aspects of collecting corn stover for bioenergy. Biomass Bioenerg. 23:347-55.

Soldano M, Labartino N, Fabbri C, Piccinini S, 2012. Biochemical methane potential (BMP) test of residual biomass from the agrofood industry. pp 1420-3 in Proc. 20th European Biomass Conference and Exhibition, Milan, Italy.

Stürmer B, Schmid E, Eder MW, 2011. Impacts of biogas plant performance factors on total substrate costs. Biomass Bioenerg. 35:1552-60.

UNI (Ente Italiano di Normazione), 2004. UNI EN ISO 11734:2004. Qualità dell'acqua - Valutazione della biodegradabilità anaerobica ultima di composti organici in fanghi digeriti - Metodo per misurazione della produzione di biogas. Available from: http://store.uni.com/magento-1.4.0.1/index.php/uni-en-iso-117342004.html

Wehrspann J, 2009. Concept cob collectors. Farm industry news. Available from: http://farmindustrynews.com/farm-equipment/concept-cob-collectors 